УдК 351

A. М. Есауленко, слухач магістратури кафедри управління охороною здоров' я та публічного адміністрування, Начіональний університет охорони здоров' я Украӥни імені П. А. Шупика

ORCID ID: 0000-0002-3581-6523

C. П. Кошова,

к. держ. упр., дочент, старший викладач кафедри управління охороною здоров' я та публічного адміністрування, Начіональнии університет охорони здоров' я України імені П. А. Шупика

ORCID ID: 0000-0002-7637-4311

DOI: $10.32702 / 2306-6814.2021 .15 .114$

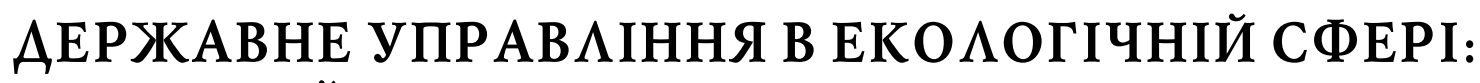 ПРАВОВИЙ АСПЕКТ
}

\author{
A. Yesaulenko, \\ Master's student of the Department of Healthcare Management and Public Administration, \\ Shupyk National Healthcare University of Ukraine Kyiv, Ukraine \\ S. Koshova, \\ $\mathrm{PhD}$ in Public Administration, Associate Professor of the Department of Healthcare Management \\ and Public Administration, Shupyk National Healthcare University of Ukraine Kyiv, Ukraine
}

\section{PUBLIC ADMINISTRATION IN THE ENVIRONMENTAL SPHERE: THE LEGAL ASPECT}

Статтю присвячено актуальним проблемам правового забезпечення державного управління в екологічній сфері України, зокрема правовим заходам, генезі та механізмам, пріоритетним напрямам екологічної політикидержави, аналізуправового регулювання, правових форм та способів гарантування якості довкілля.

Устатті розглянуто ряд вітчизняних та міжнародних нормативно-правових актів, пов'язаних із забезпеченням правалюдини на безпечне довкілля. Наведеноприклади механізмівдержавного управління в екологічній сфері. Проаналізовано ідеї вітчизняних та зарубіжних науковців з приводу правового забезпечення екологічної політики.

У сучасних умовах суспільного розвитку серед пріоритетів національних інтересів України особливо виділяється забезпечення екологічно та техногенно безпечних умов життєдіяльності громадян і суспільства, збереження і відновлення навколишнього природного середовища. На сьогодні доведено пряму залежність між забрудненням довкілля і сутєєим погіршенням здоров 'я населення, негативними змінами в його генофонді. В таких умовах актуальність і значимість права громадян на безпечне для життя і здоров'я навколишнє природне середовище набуває особливої гостроти. Охорона івідновлення довкілля, якзагальної системижиттєзабезпеченнялюдини, перетворюється взадачупершорядноїважностіз точки зорузбереження генофондународу України, а також перспектив економічного ісоціального розвитку.

У роботі встановлено, що на сучасномуетапі екологія продовжує перебувати під негативним впливом виробничої діяльності. Україна не є виключенням з цього правила і намагається вирішувати зазначену проблемуназаконодавчому рівні. Однакнормативно-правовабаза векологічній сферіпотребує кодифікації.

Сучасний стан довкілля в Україні характеризується кризовими явищами. Подібна ситуація зумовлена довготривалим згубним ставленням по відношенню до ресурсів та природи країни. Народне господарство можна охарактеризувати якдеформоване, що виражається в тривалому пріоритетірозвитку небезпечних для довкілля промислових галузей, а саме - сировинних. Масштабне підвищення уваги до проблем екології на межі минулого та нинішнього століть визначають потребу в появі повноцінного підходу до аналізу правового аспекту екологічної політики.

The article is devoted to topical issues of legal support of public administration in the environmental sphere of Ukraine, including legal measures, genesis and mechanisms, priority areas of environmental policy, analysis of legal regulation, legal forms and ways to ensure environmental quality.

The article considers a number of domestic and international regulations related to the human right to a safe environment. Examples of mechanisms of public administration in the ecological sphere are given. The ideas of domestic and foreign scientists on the legal support of environmental policy are analyzed.

In modern conditions of social development among the priorities national interests of Ukraine, the provision of ecologically and technogenically safe living conditions of citizens and society, preservation and restoration of the surrounding natural environment. To date, there is a direct relationship between environmental pollution and significant deterioration in public health, negative changes in its gene pool. In such conditions, the relevance 
and significance of the right of citizens to a safe environment for life and health becomes special severity. Protection and restoration of the environment, as a general system of human life, is becoming a task of paramount importance with in terms of preserving the gene pool of the people of Ukraine, as well as prospects for economic and social development.

It is established in the work that at the presentstage the ecology continues to be under the negative influence of production activity. Ukraine is no exception to this rule and is trying to address this issue at the legislative level. However, the regulatory framework in the environmental field needs codification.

The current state of the environment in Ukraine is characterized by crisis phenomena. This situation is due to the long-term destructive attitude towards the resources and nature of the country. The national economy can be characterized as deformed, which is expressed in the long-term priority of the development of environmentally dangerous industries, namely - raw materials. The large-scale increase in attention to environmental issues at the turn of the past and present centuries determines the need for a full-fledged approach to the analysis of the legal aspect of environmental policy.

Ключові слова: екологія, державне управління, екологічна політика, праЪо на безпечне довкілля, навколишне середовище.

Key words: ecology, public administration, ecological policy, right to safe environment, environment.

\section{ПОСТАНОВКА ПРОБАЕМИ}

На сучасному етапі розвитку суспільства серед основних напрямів політики України постає забезпечення екологічних прав населення держави. Вони полягають у захисті навколишнього середовища, створенні безпечних екологічних умов життя. Взаємозв'язок між проблемами зі здоров'ям людини та поганим станом екології $\epsilon$ науково обгрунтованим фрактом. Подібний стан речей зумовлює актуальність та важливість дослідження такого питання, як забезпечення громадянських прав на безпечне довкілля. Охорона і відновлення довкілля, як загальної системи життєзабезпечення людини, перетворюється в задачу першорядної важливості з точки зору збереження генофонду народу України, а також перспектив економічного і соціального розвитку.

Серйозний тиск на екологічне середовище в нашій державі та в світі загалом продовжується, попри намагання прогресивної частини соціуму вплинути на цей пресинг. Водночас у багатьох державах протягом останнього проходять трансфрормації в сфрері екологічної політики. Прагматизм і екстенсивне природокористування поступово змінюються на принципи гармонізації взаємин людини ідовкілля, пошуки стратегії стійкого розвитку суспільства і біосфрери. Екологія стає сфрерою політичних інтересів і рішень, а політика дедалі більше враховує екологічні чинники.

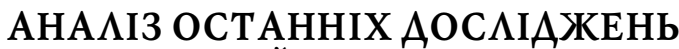 І ПУБАІКАЦІЙ}

Питання правового забезпечення державного управління в екологічній сфрері $\epsilon$ досить актуальним на сучасному етапі та має значний інтерес з боку вчених, правників, філософрів, політологів. Так, теоретичні аспекти правового забезпечення екологічної політики України, проблематику державного управління в екологічній сфрері досліджуються в працях О. Заржицького, В. Андрейцева, А. Качинського, Г. Хміль, А. Гетьман, В. Бередіхтіна. Аналіз актуальних проблем екологічного права України представлений в наукових розробках дослідників М. Краєвої, В. Попова, М. Шульги.

\section{META CTATTI}

Метою статті $\epsilon$ дослідження нормативно-правової бази екологічної політики в України, аналіз правових аспектів державного управління в сфрері збереження та захисту довкілля, визначення основних проблем правового регулювання якості довкілля як стратегічного напряму екологічної політики України.

\section{ВИКААА ОСНОВНОГО МАТЕРІААУ}

Розглядаючи поняття екологічної політики в якості системи заходів, направлених владою та соціумом на збереження та захист навколишнього середовища, дієвого синтезу користування екологічними благами та їх охороною, захисту здоров'я населення держави, варто виділити два аспекти - нормативний і регуляційний. Нормативний вимір являє собою набір норм. Регуляційний аспект представляє саму діяльність, спрямовану на захист довкілля. Що стосується основи екологічної політики, то вона грунтується на Конституції України. Головні принципи зазначеного вектору державної політики зазначені в Законі України "Про охорону навколишнього природного середовища" та статті 3 цього нормативно-правового акту [7, c. 23]. На основі узагальнення вітчизняного та зарубіжного досвіду формування механізмів вирішення соціальних $\mathrm{i}$ екологічних проблем визначають такі принципи екологічної політики України у перехідний період:

- пріоритет екології над економікою, поступовий та поетапний перехід до нових механізмів державного управління у сфері реалізації екологічної політики;

- відповідність механізму державного управління у сорері реалізації екологічної політики фактичному стану розвитку суспільства;

- узагальнення позитивного вітчизняного та зарубіжного досвіду з метою вирішення екологічних проблем;

- участь держави у фінансуванні екологічних проблем;

- забезпечення сталого і невиснажливого природокористування;

- неперервне екологічне виховання, екологічна освіта й отримання екологічної інфоормації [1, с. 46].

Головне місце в питаннях прийняття рішень на рівні держави посідають центральні органи виконавчої гілки влади - міністерства та державні комітети. До їх завдань відноситься регулювання користування природними ресурсами, їх захисту, забезпечення екологічного обгрунтування необхідності створення проєктів господарювання, організація та реалізація освіти в сфері екології, проведення моніторингів [7, с. 23-24]. 
До головних інструментів забезпечення відповідної політики в державі відносять пільги, податки, нормативно-правові акти центральних органів державної влади, засоби масової інформації. Зазначені інструменти екологічної політики в Україні можна віднести до адміністративних, правових, інформаційно-освітніх груп. Окремо визначаються основні засоби державного управління в екологічній сфрері, а саме: заходи охоронного характеру, економічна регуляція та мотивування діяльності в сорері збереження довкілля, заходи примусового та спонукального характеру. Загалом екологічна політика $€$ окремим вектором управління державою [3, с. 5].

Під поняттям "державне управління" розуміють діяльність, що $є$ направленою на виконання нормативноправових документів завдяки використанню різноманітних засобів впливу на соціальні процеси та їх наслідки. До об'єкту управління входить переважна частина сфер життєдіяльності, а визначальним принципом цього виду діяльності є підпорядкованість. Це зумовлює той фракт, що головним методом управління $€$ державні правові акти. Державне регулювання передбачає здійснення комплексних заходів у сорері екологічної політики з метою їх упорядкування, встановлення загальних норм і правил суспільної поведінки для охорони живої і неживої природи навколишнього середовища, захисту здоров'я та життя населення, організації та підтримування раціонального використання і відтворення природних ресурсів. За умови ефективного функціонування державного регулювання включається потреба прямого втручання держави та її інституцій у діяльність екологічних структур [7, с. 24]

Станом на сьогодні регіони країни $€$ повноцінним суб'єктом в системі екологічної політики держави. Подібний стан речей зумовлений одним із пунктів Основного Закону України, згідно з яким устрій держави включає в себе соборність українських земель, цілісність централізації та децентралізації в реалізації державного управління, гармонічність економічного та суспільного поступу різних частин країни з оглядом на регіональну специфіку, народні традиції. Звертаючи увагу на сучасний стан довкілля, вагому роль соціальних взаємин у сфері екології, місце управління екологічною політикою відводиться органам державної влади. Саме держава формує вектори політики щодо збереження та захисту навколишнього середовища як держави загалом, так іїї окремих регіонів [8, с. 44-45].

Держава надає органам місцевої влади дієві важелі задля реалізації екологічної політики. Стаття 13 Конституції України затверджує тезу про перебування повітря, ресурсів, землі, природних надр, водоймищ Української держави у власності народу. Саме зайого делегуванням функції власника виконуються місцевою владою [10]. Місцеві ради мають більше всього повноважень у сфері регіональної політики охорони довкілля. Це забезпечує нормативно-правова база. Так, ЗУ "Про місцеве самоврядування", надає зазначеним органам місцевого самоврядування можливості створювати цільові програми розвитку регіону з різних питань, в тому числі й тих, що стосуються навколишнього середовища, розв'язувати проблеми, що стосуються видачі дозволів на користування надрами регіону, організовувати захист природних об'єктів місцевого значення, якщо вони потребують такої охорони, визначати об'єкти екології, що мають особливу цінність [7, с. 24].
До одних із найголовніших стратегічних завдань України в 21 столітті відносяться такі, пов'язані з екологічною сфрерою:

- захист та оздоровлення екологічних систем держави;

- забезпечення сталого економічного розвитку;

— захист та збереження об'єктів ландшафртута біології;

- врахування міжнародного досвіду та стандартів у процесі реалізації державного управління в сорері екологічної політики;

- підвищення рівня відповідальності за дії, спрямовані на реалізацію екологічної політики [1, с. 48].

Нове покоління прав людини, яке продовжує формуватися в наш час, включає в себе право людини на безпечну екологію. Його розвиток відбувається під впливом як і трансформації законодавчої бази, так і теоретичних досліджень [3]. Підвищення інтересу до питань екології з боку вітчизняних науковців почалося у 1960-х роках, одночасно з прийняттям відповідних нормативно-правових актів. Прийнятий в 1960 році Закон "Про охорону природи Української Радянської Соціалістичної Республіки" тлумачив поняття захисту екології як комплекс дій, спрямованих на збереження природних багатств, їх розвиток та адекватну експлуатацію. Державній охороні та регулюванню використання на землях Української РСР підлягали: земля, надра, водні ресурси, ліси, полезахисні й водоохоронні лісові смуги, зелені насадження, типові ландшафти, курортні місцевості, рідкісні й визначні природні об'єкти, державні заповідники та заказники, фауна, повітря та інші природні ресурси, що знаходяться в господарському використанні, а також ті, що не використовуються [4].

Досліджуючи правовий аспект еволюції створення права на безпечну екологію, варто виділити той факт, що до 1960-х років поняття екологічного права не мало юридичної та правової основи. Водночас фундамент законодавчого регулювання майбутнього права на безпечне довкілля, почав закладатися по закінченню Другої Світової війни [5, с. 17].

Юридичне формування екологічного права почалося з Конференції Організації Об'єднаних Націй, яка відбулася в столиці Швеції 1972 року [16]. Під час проведення вказаного заходу були визначені та обговорені питання, що стосувалися права людини на безпечне довкілля. Внаслідок Стокгольмської конфреренції Декларація з навколишнього середовища була прийнята на міжнародному рівні [7, с. 25].

Внаслідок досліджень правового аспекту сорери навколишнього середовища наприкінці XX ст. науковцями була розроблена концепція раціонального використання екологічних багатств, захисту екології. Зазначена дослідницька база знайшла своє відображення в Законі України "Про охорону навколишнього природного середовища" від 25 червня 1991 року [5, с. 17].

У 1990-х роках в Україні формувалися шляхи вирішення екологічних проблем на законодавчому рівні. Вагома роль у цьому питанні приділялася ядерній безпеці України. Було зрозуміло, що поступ молодої держави неможливий без створення складної та ефективної структури її безпеки. У вирішенні цих завдань особливо відповідальна роль належить Концепції національної безпеки України, яка була схвалена Верховною Ра- 
дою України 16 січня 1997 р. [7, с. 26]. Вона визначала національну безпеку в якості стану безпеки по відношенню до громадян, країни від внутрішніх і зовнішніх загроз, що $\epsilon$ необхідною умовою збереження та примноження духовних і матеріальних цінностей. Головними об'єктами національної безпеки є:

- громадянин - його права і свободи;

- суспільство - його духовні і матеріальні цінності;

- держава - іï Політика національної безпеки здійснюється з метою уникнення чинників, які погіршують життя людей, знищують потенціал нормального розвитку країни [9, с. 8-9].

Політика держави в екологічній сорері в контексті національної безпеки отримує пояснення з огляду на першочерговість захисту національних інтересів держави і виконується завдяки реалізації правової бази. Екологічна безпека базується на концепції всеохоплюючої системи міжнародної (глобальної) безпеки, в якій перша розглядається як органічна частина і ключовий компонент даної системи [1, с. 48].

Здійснення політики держави, реалізація державного управління не будуть ефективними без орієнтації на захист екології в якості важливого вектору розвитку держави. Екологічна безпека $є$ обов'язковим елементом безпеки самої держави. Забезпечення векторів захисту навколишнього середовища гарантує повноцінну життєдіяльність громадян країни, збереження генофонду нації [14, с. 17]. В ст. 16 Основного закону України визначено, що "забезпечення екологічної безпеки і підтримання екологічної рівноваги на території України, подолання наслідків Чорнобильської катастрофи - катастрофри планетарного масштабу, збереження генофонду Українського народу є обов'язком держави" [10]. Суспільна цінність екологічної безпеки характеризується цілим рядом принципових особливостей. Серед них - пріоритетність у системі екологічної політики держави, тобто гарантії екологічної безпеки повинні перебувати в одному ряду з гарантіями військової, державної та особистої безпеки, з гарантіями основних прав та свобод людини. Норми життєзабезпечення в сучасному суспільстві вимагають соціальних гарантій мінімуму екологічної безпеки для всіх членів суспільства незалежно від їхнього соціального та матеріального становища. Формування системи екологічної безпеки як складової національної та державної безпеки - це не простий процес, який обумовлюється складністю взаємодії екологічної безпеки з іншими соціальними цінностями, необхідність знаходити у кожному конкретному випадку розумний компроміс між екологічною безпекою та іншими соціальними цінностями $[9$, с. 9].

Правові приписи стосовно екологічної безпеки, напрямів реалізації екологічної політики містяться сьогодні як на рівні механізму конституційного, законодавчого так і підзаконного нормативно-правового регулювання. Це означає, що екологічна безпека чітко отримала "прописку" правової категорії, а норми, які регламентують відносини щодо її забезпечення, відособлюються у відносно окремий блок законодавства України як на рівні мети, її завдань, так і механізму правового забезпечення [13, с. 35].

Згідно з головними векторами екологічної політики держави, користування природними надрами і забезпечення екологічної безпеки (затверджено Постановою
Верховної Ради України від 5 березня 1998 р. № 188/ 98-ВР) для реалізації державної екологічної політики визначають три рівні управління: національний, регіональний, місцевий [15].

До фрункцій національного рівня управління належить вирішення таких питань:

- створення законодавчої та методичної основи;

- створення механізмів управління ядерної безпеки;

- формування економічного механізму природокористування;

- контроль за природокористуванням та захист екології від забруднення;

- правове визначення небезпечної для довкілля праці;

- формування політики щодо НС природного характеру та визначення їх зон;

- регулювання використання ресурсів державного значення;

- проведення єдиної науково-технічної політики щодо охорони, раціонального використання та відновлення природних ресурсів;

- проведення державної політики щодо збереження біорізноманіття;

- забезпечення екологічної безпеки як складової національної безпеки;

- дотримання умов міжнародних нормативно-правових актів у сорері екологічної політики;

- прогнозування екологічних проблем, дослідження, облік, моніторинг у сорері захисту довкілля;

- реалізації екологічної освіти [1, с. 49].

Реалізація державного управління в екологічній сорері на рівні регіонів включає в себе моніторинг місцевого природокористування, встановлення нормативів забруднення екології, забезпечення необхідних експертних аналізів, забезпечення виконання нормативно-правових актів, інформаційну політику, розробку програм тощо [7, с. 27].

Прийняття Конституції України стало важливим кроком до забезпечення захисту довкілля. Стаття 16 вказує на те, що саме держава забезпечує екологічну безпеку в державі. Згідно зі статтею 15 кожен громадянин України може отримати інфрормації про навколишнє середовищ. Стаття 66 Конституції в свою чергу вказує на відповідальність громадян за нанесення школи навколишньому середовищу своїми діями [10].

Реалізацією державного управління в економічній сорері займається Міністерство захисту довкілля та природних ресурсів України. Зазначений орган виконавчої влади відповідає за контроль користування природними ресурсами, здійснює забезпечення законодавчої бази в сорері екології [7, с. 28].

Згідно з положеннями ЗУ "Про охорону навколишнього природного середовища" держава гарантує українським громадянам:

- безпечний рівень довкілля;

- право брати участь в ознайомленні з законодавчими актами, обговорювати проєкти, що стосуються екологічної сорери, приймати участь в екологічних заходах;

- здійснення загального і спеціального використання природних ресурсів;

- можливість створювати суспільні об'єднання, діяльність яких спрямована на збереження та захист довкілля; 
- можливість отримання необхідної інформації від органів влади що стану навколишнього середовища;

- право участі в експертних групах з дослідження проблем навколишнього середовища

- одержання екологічної освіти;

- можливість звернення до судових органів з приводу негативного впливу на екологію [1, с. 51].

Водночас гарантія дотримання екологічних прав зумовлює появу обов'язків, яких громадяни повинні дотримуватися. Так, кожен громадянин України повинен зберігати та захищати навколишнє середовище, адекватно користуватися природними багатствами, дотримуватися норм законодавчих актів в екологічній сфері. Також до обов'язків громадян, згідно зі статтею 12 вищезазначеного закону, відносяться дотримання встановлених вимог до безпеки довкілля, обмежувати користування природними ресурсами, своєю діяльністю не порушувати прав інших громадян в екологічній сфері, відшкодовувати збитки, що були нанесені навколишньому середовищу своїми діями [7, с. 28].

Право людей на безпечне навколишнє середовище реалізовується завдяки гарантіям держави. До них можна віднести організацію заходів державного рівня, метою яких є збереження довкілля та природних багатств, проведення відповідними органами виконавчої влади заходів технічного характеру щодо збереження екології, дотримання встановлених вимог під час створення, розташуванні об'єктів господарства, контроль за виконання вимог, встановлених законодавчими актами в екологічній сфері, відшкодування збитків, що були спричинені порушенням встановлених державою вимог у сфері екологічної політики [9, с. 12].

В структуру державних заходів, які направлені на забезпечення права людей на безпечне довкілля, входять:

- експертизи, контроль і нагляд у галузі охорони навколишнього природного середовища;

- спеціальні програми;

- екологічна освіта.

Спеціальні програми для екологічної сорери створюються задля реалізації успішної та систематичної роботи з проведення природоохоронних заходів, для безпеки навколишнього середовища, грамотного використання природних багатств. Однією з таких програм була "Програма формування національної екологічної мережі України на 2000-2015 рр.", загальнодержавна Програма поводження з токсичними відходами; загальнодержавна Програма охорони та відтворення довкілля Азовського і Чорного морів [1, с. 61 ].

Зу "Про екологічну експертизу" зазначає, що до завдання експертних досліджень відноситься попередження негативного впливу людської життєдіяльності на довкілля, аналіз рівня впливу господарської діяльності на навколишнє середовище країни, окремих регіонів. Значимим елементом правового регулювання державного управління в екологічній сфері $є$ контроль за безпекою довкілля. Він здійснюється на громадському та державному рівнях [7, с. 30].

Варто зазначити, що тиск на навколишнє середовище не зменшується, що зумовлено підвищенням виробництва, відсутністю економічних інструментів державного регулювання та страхового ринку в екологічній сорері. Запровадження екологічного страхування могло б стати одним з факторів вирішення нагальних проблем в якості елементу економічного механізму, що забезпечуватиме відшкодування збитків за негативний вплив на навколишнє середовище. Нині Кабміном створено законопроєкт, що має на меті забезпечити екологічне страхування в Україні. В разі його затвердження подібний вид страхування має стати обов'язковим для організацій, підприємств діяльність яких впливає на навколишнє середовище [11, с. 124].

Національна безпека держави, згідно з Законом "Про основи національної безпеки України", отримує забезпечення грамотною політикою влади, що відображається в створені програм, концепцій та інших проєктів у різноманітних сфрерах життєдіяльності, в тому числі і в екологічній. Визначені напрями та інструменти забезпечення національної безпеки зумовлені першочерговістю національних інтересів, потребою актуальних заходів, що мають базуватися на нормативно-правовій базі [6].

Заходи державного управління, що регулюють екологічну сферу, виражаються в діяльності по створенню законодавчих актів з екологічної безпеки з боку представників органів державної влади. До прикладів таких заходів можна віднести створення стандартів у галузі екологічної безпеки, визначення небезпечних екологічних зон, вироблення нормативної бази із захисту екології, встановлення екологічних лімітів. Наприклад, у 2000 році було затверджено Перелік організацій, що $\epsilon$ координаторами векторів наукових досліджень та Пріоритетні напрями наукової діяльності. Обидва проєкта були розроблені завдяки роботі Національної академії наук України та Міністерства з питань надзвичайних ситуацій та у справах захисту населення від наслідків Чорнобильської катастрофи [2, с. 108].

\section{ВИСНОВКИ}

Таким чином, правовий аспект державного управління в екологічній сфері здійснюється відповідно до вимог Конституції, законів України, рішень та постанов Кабінету Міністрів, Указів Президента, екологічних програм, стратегій, концепцій. Національна система забезпечення захисту екології являє собою заходи державного та регіонального рівня різноманітного характеру, направлені на підтримання балансу між екологічними системами та навантаженнями на них з боку населення. Завдання захисту навколишнього середовища забезпечуються стандартами щодо захисту екології, нормативно-правовими актами, правилами користування природними багатствами. Також державне управління в екологічній сфері забезпечується нормативами, передбаченими Законом України "Про охорону навколишнього природного середовища". Нормативи встановлюють допустимий рівень негативних викидів, допустимі грані негативного впливу на навколишнє середовище. Подібний стан речей дає змогу стверджувати, що на сучасному етапі екологічна безпека являє собою самостійний вектор національної політики.

Станом на сьогодні державне управління в екологічній сфері України забезпечується складною системою нормативно-правових актів. Водночас різна юридична сила цих актів призводить до ускладнення їх ко- 
ристуванням та зумовлює суперечності, неузгодженості. Перебування приписів у значному числі законодавчих актів призводить до ускладнень під час використання цих правових норм. З огляду на зазначене твердження, важливим завданням екологічної політики $є$ кодифікація нормативно-правових актів у вказаній сфері у вигляді комплексного припису.

\section{Література:}

1. Андрєйцев В.І. Екологічне право. К.: Вентурі, 1996. С. $46-61$.

2. Анісімова Г.В. Екологічне законодавство України: проблеми кодифікації. Харків, 2008. Вип. 97. С. 108.

3. Білобров Б. Стратегія українського державотворення: соціальні пріоритети. Людина і політика. 2000. № 1. С. 5.

4. Васильева М.И. Право граждан СССР на здоровую окружающую среду. URL: https://rusneb.ru / catalog/000199_000009_000073548/

5. Гетьман А.П. Методологічні засади становлення правових основ охорони довкілля. Право України. 2011. № 2. С. 17.

6. Закон України "Про основи національної безпеки". URL: https://zakon.rada.gov.ua/laws/show/96415\#Text

7. Заржицький О.С. Актуальні проблеми правового забезпечення екологічної політики України (теоретичні аспекти). Д.: Національний гірничий університет, 2012. С. $23-30$.

8. Заржицький О.С. Правові аспекти регіональної екологічної політики. Дніпропетровськ: Наука і освіта, 2003. С. $44-45$.

9. Качинський А.Б., Хміль Г.А. Екологічна безпека України: аналіз, прогноз, оцінка та державна політика. К.: НІСД, 1997. С. 8-12.

10. Конституція України. URL: https://zakon.rada.gov.ua/laws/show $/ 254 \%$ D0\%BA/96-\%D0\%B2\%D1\%80\#Text

11. Краєнова М.В. Компенсація шкоди за екологічним законодавством України (теоретико-правові аспекти). К.: Видавничо-поліграфрічний центр "Київський університет". 2008. С. 124.

12. Основні напрями державної політики України у галузі охорони довкілля, використання природних ресурсів та забезпечення екологічної безпеки. Затверджено Постановою Верховної Ради України від 5 березня 1998 року № 188/98. URL: https://zakon.rada.gov.ua/laws/show / 188/98-\%D0\%B2\%D1\%$80 \#$ Text

13. Попов В.К. Наукові основи екологічного законодавства України. Вісник Академії правових наук України. 1995. № 4. С. 35-36.

14. Попов В., Шульга М., Шахов В., Розмєтаєв С. Нові підходи до кодифікації екологічного законодавства України. Право України. 1992. № 3. С. 17.

15. Хёсле В. Философия и экология. URL: https:// filosoff.org/tvorchestvo/filosofiya-i-ekologiya-vxyosle /

References:

1. Andreicev, V. I. (1996), Ekolohichne pravo [Environmental law], Ventury, Kyiv, Ukraine, pp. 46-61.
2. Anisimova, H. V. (2008), "Environmental legislation of Ukraine: codification problems", Problemy zakonodavchoho rehulyuvannya poryadku rozrobky ta pryynyattya normatyvno-pravovykh aktiv: tezy dop. ta povidoml. suchasn. III Mizhnar. nauk.-prakt. konf. [Problems of legislative regulation of the procedure for development and adoption of regulations: abstracts add. and messages. modern III International. scientific-practical conf.], Pravo, Kharkiv, Ukraine, pp. 120-124.

3. Bilobrov, B. (2000), "Strategy of Ukrainian state formation: social priorities", Man and politics, vol. 1, p. 5.

4. Vasilieva, M. I. (1990), "The rights citizens of the USSR to a healthy environment", available at: https:// rusneb.ru/catalog/000199_000009_000073548/(Accessed 05 July 2021).

5. Hetman, A. P. (2011), "Methodological bases of legal bases of environmental protection", Law of Ukraine, vol. 2 , p. 17.

6. Verkhovna Rada of Ukraine (2018), The Law of Ukraine "On Fundamentals of National Security", available at: https: / / zakon.rada.gov.ua/laws/show /96415\#Text (Accessed 05 July 2021).

7. Zarjickii, O. S. (2012), Aktual'ni problemy pravovoho zabezpechennia ekolohichnoi polityky Ukrainy (teoretychni aspekty) [Actual problems of support of ecological policy of Ukraine (theoretical aspects)], National Mining University, Dnepropetrovsk, Ukraine, pp. 23-30.

8. Zarjickii, O. S. (2003), Pravovi aspekty rehional'noi ekolohichnoi polityky [Legal aspects of regional environmental policy[, Nauka i osvita, Dnepropetrovsk, Ukraine, pp. $44-45$.

9. Kachinskii, A. B. and Khmil, H. A. (1997), Ekolohichna bezpeka Ukrainy: analiz, prohnoz, otsinka ta derzhavna polityka [Ecological security of Ukraine: analisis, forecast, assessment and state policy], NISS, Kyiv, Ukraine, pp. 8-12.

10. Verkhovna Rada of Ukraine (1996), "The Constitution of Ukraine", available at: https://zakon.rada.gov.ua/laws/show /254\%D0\%BA/96-\%D0\%B2\%D1\%80\#Text (Accessed 05 July 2021).

11. Kraenova, M. V. (2008), Kompensatsiia shkody za ekolohichnym zakonodavstvom Ukrainy (teoretykopravovi aspekty) [Compensation for damage under the environmental legislation of Ukraine (theoretical and legal aspects)], Publishing and Printing Center "Kyiv Univercity", Kyiv, Ukraine. 124.

12. Verkhovna Rada of Ukraine (1998), Resolution "The main directions of Ukraine's state policy in the field of environmental protection, use of natural resources and environmental safety", available at: https://zakon.rada.gov.ua/laws / show / 188/98-\%D0\% B2\%D1\%80 \#Text (Accessed 05 July 2021).

13. Popov, V. K. (1995), "Scientific bases of ecological legislation of Ukraine", Bulletin of the Academy of Legal Sciences of Ukraine, vol. 4, PP. 35-36.

14. Popov, V. Shulga, M. Shakhov, V. and Rozmetaev, S. (1992), "New approaches to codification of environmental legislation of Ukraine", Law of Ukraine, vol. 3, p. 17.

15. Hesle, V. (1991), "Philosophy and ecologi.", available at: https://filosoff.org/tvorchestvo/filosofiya-iekologiya-v-xyosle / (Accessed 05 July 2021). Стаття надійшла до редакцї̈ 14.07.2021 p. 